\title{
EVALUASI PELAKSANAAN CLASSROOM ASSESMENT DI MADRASAH TSANAWIAYAH DDI SEPPANGE KECAMATAN BENGO KABUPATEN BONE
}

\author{
St. Jumaeda ${ }^{1}$ \\ Prodi PAI FITK IAIN Ambon \\ Jumaeda@iainambon.ac.id \\ St. Nur Alam² \\ Guru MTS DDI Seppange \\ Nuralam.hannani@gmail.com
}

\begin{abstract}
This study aims to evaluate the implementation of classroom assessment on: (1) aspects of classroom assessment, 2) classroom assessment techniques, and (3) classroom assessment procedures. This research is a survey study, using a formative evaluation model from Michael Scriven.Sampling techniques are purposive samples. The research location is MTs DDI Seppange. Data collection is obtained through questionnaires, interviews, observations, and documentation. Data analysis techniques used are qualitative analysis techniques. The results showed that: (1) classroom assessment techniques carried out by MTS DDI Seppange teachers include written tests, observations, practical tests, assignment assessments, and oral tests, portfolios, journals, peer-to-peer assessment and self-assessment (2) aspects of classroom assessment that have been carried out by teachers covering cognitive, psychomotor, and affective aspects, (3) Classroom assessment procedures that have been carried out by teachers include making question grids, grain analysis, remedial implementation, and follow-up assessment results. The evaluation of aspects, techniques, and class assessment procedures, teachers at MTS DDI Seppange were carried out properly.
\end{abstract}

Keywords: Evaluation, classroom assessment, teachers,

Abstrak: Penelitian ini bertujuan untuk mengevaluasi pelaksanaan classroom assessment tentang: (1) aspek-aspek classroom assessment, 2) teknik-teknik classroom assessment, dan (3) prosedur classroom assessment. Penelitian ini adalah penelitian survei, dengan menggunakan model evaluasi formatif dari Michael Scriven.Teknik pengambilan sampel adalah purposive sample. Lokasi penelitian adalah MTs DDI Seppange. Pengumpulan data diperoleh melalui angket, wawancara, observasi, dan dokumentasi. Teknik analisa data yang digunakan adalah teknik analisis kualitatif. Hasil penelitian menunjukkan bahwa: (1) teknik classroom assessment yang dilaksanakan guru MTS DDI Seppange meliputi tes tertulis, observasi, tes praktik, penilaian tugas, dan tes lisan, portofolio, jurnal, penilaian antar teman dan penilaian diri (2) aspek-aspek classroom assessment yang telah dilaksanakan guru meliputi aspek kognitif, psikomotorik, dan aspek afektif, (3) Prosedur classroom assessment yang telah dilaksanakan guru meliputi pembuatan kisi-kisi soal, analisis butir soal, pelaksanaan remedial, dan tindak lanjut hasil penilaian. Hasil evaluasi tentang komponen aspek, teknik,dan prosedur penilaian kelas, guru di MTS DDI Seppange terlaksana dengan baik.

Kata kunci: Evaluasi, penilaian kelas, guru, 


\section{PENDAHULUAN}

Penilaian yang baik dan cermat akan memberikan deskripsi proses dan output hasil belajar yang objektif. Sehubungan dengan itu Mardapi mengatakan bahwa sistim penilaian yang digunakan di lembaga pendidikan harus mampu: (1) memberikan informasi yang akurat, (2) mendorong peserta didik belajar, (3) memotivasi tenaga pendidik mengajar, (4) meningkatkan kinerja lembaga, dan (5) meningkatkan kualitas pendidikan. (Mardapi, 2005: 75).

Sejak kurikulum berbasis kompetensi diberlakukan dan adanya Peraturan Pemerintah Nomor 19 Tahun 2005 pasal 19 ayat 1, "proses pembelajaran pada satuan pendidikan diselenggarakan secara aktif, inspiratif, menyenangkan, menantang, memotivasi peserta didik untuk berpastisipasi aktif, serta memberikan ruang yang cukup bagi prakarsa, kreativitas, dan kemandirian sesuai dengan bakat, minat, dan perkembangan fisik serta psikologis peserta didik. (PP no. 19 tahun 2005)

Pendekatan pembelajaran yang dikembangkan adalah pembelajaran aktif, kreatif, efektif dan menyenangkan (PAKEM), kemudian dalam penilainnya dikembangkan classroom assessment. Dengan melaksanakan pendekatan PAKEM dan classroom assessment dalam pembelajaran diharapkan mendukung keberhasilan dan inovasi kurikulum. Hal tersebut senada dengan pendapat Mundilarto menyatakan bahwa dalam rangka penerapan kurikulum berbasis kompetensi ada empat hal yang perlu mendapat perhatian yakni: (1) pengembangan program, (2) pelaksanaan pembelajaran, (3) penilaian belajar, dan (4) peningkatan kualitas pembelajaran. (Mundiarto, 2005: 1) Oleh karena itu, upaya peningkatan kualitas pendidikan melalui perubahan kurikulum akan nampak dengan melakukan perbaikan dalam pelaksanaan sistem penilaian.

Penilaian hasil belajar yang dilakukan oleh pendidik dan satuan pendidikan merupakan penilaian internal (internal assessment), sedangkan penilaian yang diselengarakan oleh pemerintah merupakan penilaian eksternal (external assessment). Penilaian internal merupakan penilaian yang dilaksanakan dan dilakukan oleh pendidik pada saat dan setelah proses pembelajaran berlangsung dalam rangka penjaminan mutu. Penilaian oleh satuan pendidikan dilakukan untuk menilai pencapain standar kompetensi lulusan sebagai dasar pertimbangan untuk 
menentukan kelulusan peserta didik dari satuan pendidikan. Penilaian eksternal yang dilakukan oleh pemerintah sebagai pengendali mutu.

Penilaian pada dasarnya merupakan upaya memperoleh informasi secara komprehensif mengenai kekuatan, kelemahan dan kemajuan belajar siswa yang meliputi aspek kognitif, afektif, dan psikomotor. Aspek kognitif dapat berupa konsep, prinsip, teori, dan hukum alam yang merupakan hasil telaah produk dari proses ilmiah para ahli. Aspek psikomotor dapat berupa keterampilan mengamati, menghitung, mengklasifikasi, mengukur, memprediksi dan mengkomuniksikan hasil. Aspek afektif dapat berupa nilai-nilai dan sikap ilmiah seperti sikap objektif berpikir bebas, tidak berprasangka, dan disiplin.

Penilaian oleh guru dapat diketahui dari segi perencanaan, pelaksanaan dan pelaporan hasil belajar siswa. Perencanaan penilaian dapat terdeteksi melalui silabus, rencana pelaksanaan pembelajaran, dan kisi-kisi soal dalam penilaian yang digunakan guru. Pelaksanaan penilaian dapat dilihat dari dokumen siswa dan buku penilaian guru. Pelaporan hasil belajar siswa dapat dilihat dari buku laporan (rapor) hasil belajar siswa.

Akibat dari kurang komprehensifnya penilaian yang dilaksanakan guru, masyarakat sebagai pengguna jasa pendidikan sering mengeluh dan kecewa terhadap produk pendidikan. Mereka menilai institusi pendidikan kurang mampu menghasilkan sumber daya manusia yang memiliki kemampuan yang tangguh dan terampil, jika ditinjau dari segi aspek kognitif, aspek afektif, dan aspek psikomotorik.

Dominannya penilaian pada aspek kognitif dapat mempengaruhi cara siswa belajar dan cara guru mengajar. Kelemahan penilaian yang dilakukan guru selama ini, selain terletak pada aspek yang dinilai juga cara penilaian, yaitu bergantung pada tes tertulis (paper and pencil test). Model penilaian seperti ini, baik tes standar maupun tes buatan guru masih merupakan kekuatan yang mempengaruhi pola pembelajaran yang dilakukan guru. Guru dalam mengajar lebih bersifat driil meninggalkan aspek proses, sehingga siswa kurang terampil dalam menyelesaikan masalah-masalah, siswa lebih banyak diberikan tentang cara dan kiat menjawab soal-soal tes, hal tersebut sudah tradisi bahkan dianggap menjadi strategi yang mengklasik. Untuk mengatasi kelemahan tersebut pemerintah melalui Pusat Penilaian Pendidikan (Puspendik) dan Badan Standar Nasional Pendidikan (BSNP) 
Departemen Pendidikan Nasional menggalakkan pelaksanaan penilaian kelas (classroom assessment).

Dalam buku Pedoman Penilain Kelas dinyatakan bahwa penilaian kelas merupakan suatu proses yang dilakukan melalui langkah-langkah perencanaan, pengumpulan informasi melalui sejumlah bukti yang menunjukkan pencapaian hasil belajar peserta didik, pelaporan, dan penggunaan informasi tentang hasil belajar peserta didik. Penilaian kelas dapat dilaksanakan melalui penilaian kinerja, penilaian penugasan, penilaian hasil kerja, penilaian tes tertulis, penilaian portofolio, dan penilaian sikap. (Muslich, 2007:80) Selaras dengan itu, Tola menyatakan bahwa penilaian berbasis kelas sangat urgen, karena penilaian kelas dapat dikreasi, dikelola, dianalisis dan dinilai oleh guru, dan siswa sendiri mengenal masalah mengajar dan belajar. (Tola, $2010: 7-8$ )

Penilaian berbasis kelas merupakan suatu pendekatan yang didesain untuk membantu guru menemukan bagaimana individu atau kelompok siswa sedang belajar dalam kelas. Jika guru berhasil menerapkan hasil penilaiannya sendiri untuk memperbaiki caranya mengajar dan siswa dapat mengunakan hasil pencapaiannya sendiri untuk memperbaiki kemampuan merupakan suatu perubahan mendasar dalam meningkatkan mutu pendidikan.

Kurikulum 2013 menuntut guru untuk dapat melaksanakan sistem classroom assessment yang dilaksanakan dengan baik dan diharapkan dapat mewarnai perubahan kurikulum pendidikan nasional. Inovasi kurikulum mengharapkan adanya sumber daya manusia yang terampil, bernurani, dan mandiri dapat tersebar di seluruh Indonesia, mengikis fenomena pengetahuan generasi bangsa yang tidak berbanding lurus dengan keterampilan dan sikapnya. Oleh karena itu, sistim classroom assessment harus memperhatikan aspek kognitif, afektif, dan psikomotorik melalui penggunaan teknik penilaian tertulis, penilaian tes lisan, penilaian hasil kerja siswa, penilaian projek, penilaian portofolio, penilaian jurnal, penilaian diri dan penilaian antarteman diharapkan mampu mengatasi multi krisis sekarang ini.

Penilaian kelas dilaksanakan melalui berbagai cara, seperti penilaian unjuk kerja (performance), penilaian sikap, penilaian tertulis (paper and pencil test), penilaian tes lisan, penilaian projek, penilaian produk, penilaian melalui pengumpulan hasil kerja/karya peserta didik (portofolio), penilaian diri dan penilaian 
antarteman. Teknik penilaian tersebut digunakan untuk memperoleh data sebagai informasi yang diandalkan sebagai dasar pengambilan keputusan. Keputusan tersebut berhubungan dengan sudah atau belum berhasilnya peserta didik dalam mencapai suatu kompetensi. Dengan penilaian kelas guru dapat menjaring dan mengumpulkan informasi melalui prosedur, teknik dan alat penilaian yang sesuai dengan kompetensi yang akan dinilai selama dan setelah proses pembelajaran. Oleh sebab itu, penilaian kelas lebih merupakan proses pengumpulan dan penggunaan informasi oleh guru untuk memberikan keputusan, dalam hal ini nilai terhadap hasil belajar peserta didik berdasarkan tahapan belajarnya. Dari proses ini diperoleh potret/profil kemampuan peserta didik dalam mencapai sejumlah standar kompetensi dan kompetensi dasar yang tercantum dalam kurikulum. Oleh karena itu penilaian kelas merupakan salah satu pilar dalam pelaksanaan kurikulum yang berorientasi kepada kompetensi.

Menurut Kamil tujuan penilaian kelas oleh guru diarahkan pada empat hal yaitu: “(1) penelusuran (keeping track), yaitu untuk menelusuri agar proses pembelajaran anak didik tetap sesuai dengan rencana, (2) pengecekan (checkingup), yaitu untuk mengecek adakah kelemahan-kelemahan yang dialami anak didik dalam proses pembelajaran, (3) pencarian (finding-out), yaitu untuk mencari dan menemukan hal-hal yang menyebabkan terjadinya kelemahan dan kesalahan dalam proses pembelajaran, dan (4) penyimpulan (summing-up), yaitu untuk menyimpulkan apakah anak didik telah menguasai seluruh kompetensi yang ditetapkan dalam kurikulum atau belum". (Yulbetri Kamil, 2008: 2) Sementara itu menurut Sudjana tujuan penilaian yaitu: (1) perbaikan sistem, (2) pertanggungjawaban kepada pemerintah dan masyarakat, dan (3) penentuan tindak lanjut hasil pengembangan. ( Nana Sudjana, 2004: 217).

Dalam melaksanaan penilaian yang baik perlu diperhatikan prinsip-prinsip penilaian sebagai dasar pada penilaian. Prinsip-prinsip penilaian kelas menurut Hayat adalah: 1) mengacu ke kemampuan, 2) berkelanjutan, 3) didaktis, 4) menggali informasi, dan 5) melihat yang benar dan salah. (Nana Sudjana, 2004: 2017-218). Sehubungan dengan prinsip tersebut, penilaian untuk belajar merupakan bagian efektif dari perencanaan pembelajaran. Suatu perencanaan perlu memberikan kesempatan kepada guru dan siswa untuk memperoleh dan menggunakan informasi tentang kemajuan tujuan pembelajaran. 


\section{METODE PENELITIAN}

penelitian ini penelitian evaluatif menggunakan metode survei. Pada penelitian evaluatif ini, metode survei dimaksudkan untuk mendeskripsikan dan menjelaskan komponen-komponen dan aspek-aspek yang dievaluasi secara sistematis, faktual, dan akurat. (Djujun Sudjana, 2006: 107). Metode penelitian survei dapat dipergunakan untuk melakukan evaluasi manakala suatu program sedang berlangsung atau sudah selesai dilaksanakan. Penelitian evaluatif yang memakai metode survei terdiri dari dua tahap, yaitu tahap teoretisasi dan tahap empirisasi. Tahap teoretisasi berupa pengkajian teoritis tentang unsur-unsur penelitian dan substansi objek yang diteliti, sedangkan tahap empirisasi merupakan suatu proses penelitian dilapangan untuk mengumpulkan data dan kemudian menganalisisnya. ( Sofian Efendi, 1995: 16-17)

Dalam penelitian evaluasi program ini, pemilihan informan dilakukan dengan teknik purposive sample, yaitu berdasarkan pertimbangan dan tujuan penelitian. Yang terdiri dari: (1) guru dengan jumlah 16 guru (2) Kepala Madrasah, dan (3) Siswa dengan jumlah 30.

Teknik pengumpulan data yang digunakan pada penelitian ini adalah

1. Kuesioner (angket)

Kuesioner merupakan teknik pengumpulan informasi dengan membuat sejumlah pertanyaan yang harus diisi oleh informan berdasarkan pada komponen dan indikator evaluasi bersangkutan. Teknik kuesioner digunakan untuk pengumpulan data aspek classroom assessment, teknik classroom assessment, dan prosedur classroom assessment tentang pelaksanaan classroom assessment di MTs DDI Seppange.

\section{Wawancara}

Wawancara adalah proses memperoleh keterangan untuk tujuan penelitian dengan cara tanya jawab sambil bertatap muka antara pewawancara dengan informan. (Burhan Bungin, 2009:108) Wawancara dilakukan dengan menggunakan pedoman wawancara dengan melibatkan empat komponen yaitu: isi pertanyaan, pewawancara, informan, dan situasi pewawancara. Wawancara digunakan untuk memdapatkan data tentang pelaksanaan aspek, teknik classroom assessmen, 
prosedur classroom assessmen, tanggapan kepala madrasah, guru dan siswa tentang pelaksanaan classroom assessmen di MTs DDI Seppange.

\section{Observasi}

Observasi merupakan teknik pengumpulan informasi yang dilakukan dengan cara melakukan pengamatan langsung terhadap pelaksanaan proses pembelajaran dalam kelas dan pelaksanaan classroom assessment di MTs DDI Seppange yang dilaksanakan pada saat kegiatan pembelajaran berlangsung.

4. Studi Dokumentasi

Studi dokumentasi ini dimaksudkan untuk melihat dan menganalisis data tertulis yang digunakan dalam pelaksanaan classroom assessment di MTs DDI Seppange. Dokumentasi digunakan untuk mengumpulkan mengenai pelaksanaan aspek, teknik dan prosedur penilaian, dan dokumen-dokumen yang ada kaitannya dengan penelitian, yaitu data siswa, data guru, silabus, rencana pembelajaran, dan format penilaian yang digunakan guru.

Sesuai dengan model evaluasi yang digunakan dalam penelitian ini, maka analisis data dilakukan dengan menggunakan Model Miles dan Huberman, yaitu model analisis kualitatif melalui tiga alur kegiatan atau proses, yaitu reduksi data, penyajian data, dan penarikan kesimpulan atau verifikasi.(Sugiono, 2008:247)

\section{HASIL PENELITIAN DAN PEMBAHASAN}

\section{Evaluasi Pelaksanaan Komponen Aspek-aspek Classroom Assessment}

Classroom assessment yang dilakukan di MTs DDI Seppange dalam melakukan penilaian melibatkan tiga aspek dengan menggunakan teknik-teknik classroom assessment. Ketiga aspek penilaian yang dimaksudkan yaitu aspek kognitif, aspek psikomotorik, dan aspek afektif. Ketiga aspek tersebut terdapat pada setiap Kompetensi Dasar dalam mata pelajaran, namun kadang-kadang guru lebih mengutamakan aspek kognitif, dibanding dengan aspek psikomotorik, dan aspek afektif.

Berdasarkan hasil penelitian menunjukkan bahwa dalam pelaksanaan penilaian kelas pada aspek kognitif sudah berjalan dengan baik, ini dikarenakan dalam pengaplikasiannya di lapangan aspek kognitif tersebut memang sangat erat dengan kemampuan dasar siswa, sehingga adanya relevansi antara mata pelajaran 
dengan pengetahuan dasar siswa, serta dalam pembelajaran di dalam kelas guru lebih terfokus pada aspek kognitif dibandingkan dengan aspek yang lain ini dikarenakan sudah ada instrumen yang jelas sehingga guru mudah saja mengukur kemampuan siswa, sehingga guru terkadang lupa bahwa ada aspek yang lain yang perlu diperhatikan seperti afektif dan psikomotorik. Karena ketiga aspek ini saling berhubungan dan memiliki keterkaitan antara yang satu dengan yang lain. Ketiga aspek tersebut tidak bisa terpisahkan karena dimasa kini siswa tidak hanya dituntut pada satu aspek saja akan tetapi diharapkan mampu menggabungkan ketiga aspek tersebut. Dikatakan demikian karena salah satu faktor pendukung kemampuan kognitif siswa adalah faktor psikologis, dalam arti bahwa bisa saja siswa tersebut memiliki kecerdasan dalam aspek kognitif namun di saat mengikuti tes ujian siswa tersebut mengalami gangguan secara psikis seperti beban keluarga sehingga mengalami penurunan saat mengikuti tes, sehingga diharapkan guru tidak hanya terfokus pada satu aspek saja akan tetapi mampu mengkaleborasikan ketiga aspek tersebut.

Pada aspek afektif dalam penerapannya di lapangan guru cukup memperhatikan aspek afektif yang berkaitan dengan tingkahlaku dan sikap siswa, guru memberikan perhatian khusus dan pendekatakan secara emosional kepada siswa, dan mengukur kemampuan afektif siswa berdasarkan dari instrument penilaian sikap yang telah disediakan guru untuk masing-masing mata pelajaran. Ketiga aspek tersebut memiliki keterkaitan antara satu dengan yang lainnya sehingga dibutuhkan kombinasi untuk menutupi kekurangan masing-masing aspek tersebut.

Pada aspek psikomotorik juga guru melakukan penilaian didasarkan pada KD terkait dengan aspek psikomotorik berdasarkan dari instrument yang telah disiapkan guru terkait dengan aspek psikomotorik siswa pada semua mata pelajaran yang diajarkan di MTS DDI Seppange. Guru di MTS DDI Seppange telah memberikan perhatian khusus pada aspek psikomotorik siswa karena dalam aspek ini berkaitan dengan kreatifitas siswa. Aspek ini sangat penting untuk melihat kemampuan siswa karena terkadang ada siswa yang lemah dari segi aspek kognitif akan tetapi memiliki kemampuan psikomotorik yang tidak dimiliki oleh siswa yang lain. Untuk mengembangkan potensi tersebut guru MTS DDI Seppange memberikan 
ransangan dan dorongan melalui estrakurikuler berupa, seni olahraga, kepramukaan, dan Keagamaan.

\section{Evaluasi Pelaksanaan Komponen Tekhnik-tekhnik Classroom Assessment}

Teknik classroom assessment yang dimaksudkan meliputi: tes tertulis, observasi, tes praktik, penugasan, tes lisan, penilaian portofolio, jurnal, penilaian diri, dan penilaian antarteman.

Pada aspek tes tertulis berdasarkan responden yang ada dapat disimpulkan bahwa guru sering menggunakan tekhnik penilaian tes tertulis. Dikarenakan teknik tersebut sudah jelas instrumennya, mudah diukur serta teknik ini berada dalam kategori mudah dan tidak membutuhkan waktu yang lama sehingga guru sangat sering melaksanakan teknik penilaian ini.

Teknik Penilaian observasi juga dilakukan oleh guru dalam menilai aspek sikap (afektif) dan keterampilan (psikomotorik) siswa. Walaupun guru masih terkendala dalam membuat instrument karena minimnya pengetahuan terkait dengan hal tersebut.

Tes praktik juga dilaksanakan oleh para guru di MTS DDI Seppange didasarkan pada istrumen yang telah dibuat oleh guru didasarkan pada indicator pada setiap KD pada aspek psikomotorik (keterampilan siswa.

Pelaksanaan penilaian penugasan masih jarang dilaksanakan oleh para guru dikarenakan dalam penugasan khususnya penugasan kelompok tidak menghasilkan target yang diinginkan oleh para guru, dikatakan demikian karena dalam pembagian kelompok terdapat siswa yang cerdas dan siswa yang kemampuannya rendah karena adanya kombinasi tersebut maka yang memiliki kemampuan rendah terkadang bersifat apatis dan seolah menyerahkan sepenuhnya kepada siswa yang memiliki kemampuan tinggi. Serta penugasan kelompok ini membutuhkan waktu yang lama apalagi jika jumlah siswanya cukup banyak sehingga dalam pengoreksian yang dilakukan oleh para guru mendapat hambatan. Walaupun pada hakekatnya penilaian penugasan ini perlu karena dengan adanya penugasan akan terbangun rasa kebersamaan dan dapat membangun kerjasama antara siswa yang satu dengan siswa yang lain. Namun harapan tersebut nampaknya tidak terpenuhi dikarenakan beberapa faktor yang telah disebutkan diatas. Sementara jika penugasan individu diharapkan siswa memiliki waktu luang untuk belajar dan belajar 
untuk menyelesaikan soal-soal yang telah diberikan oleh para guru. Namun yang terjadi di lapangan justru para siswa hanya lebih sering copy paste tugas temannya sehingga untuk meningkatkan kualitas pendidikan dengan cara teknik penilaian nampaknya masih jauh dari harapan.

Pelaksanaan tes lisan sudah dilaksanakan oleh para guru namun belum optimal hal ini dikarenakan membutuhkan waktu yang lama apalagi jika madrasah tersebut memiliki banyak siswa sementara masih banyak tugas-tugas pokok yang harus dikerjakan oleh guru seperti mengajar di kelas lain.

Khususnya pelaksanaan penilaian portofolio di MTS DDI Seppange juga juga telah dilaksanakan. Berdasarkan data dilapangan ditemukan bukti fisik adanya pelaksanaan penilaian fortofolio, penilaian jurnal, penilaian diri maupun penilaian antarteman. Hasil pengamatan terhadap proses pembelajaran pdi MTS DDI Seppange menunjukkan bahwa guru telah menyiapkan format khusus untuk menilai siswa dalam penilain proses dan penilaian hasil pada ke tiga aspek yaitu kognitif, afektif dan psikomotorik.

Penilaian Jurnal ini berdasarkan data yang diambil di lapangan juga telah dilakukan untuk menilai sikap siswa. Guru di MTS DDI Seppange mempunyai catatan kecil tentang kekurangan dan kelebihan siswa sehingga guru mampu menganalisis strategi dan metode apa yang cocok diterapkan agar materi ajar dapat dipahami siswa. Penilaian diri juga dilaksanakan oleh guru di MTS DDI Seppange untuk melihat aspek sikap siswa, sekaligus melatih siswa untuk bersikap jujur. Demikian pula penilaian antar teman juga dilakukan di MTS DDI Seppange untuk melihat aspek afektif peserta didik yang dilakukan minimal 1 kali dalam 1 semester untuk semua mata pelajaran.

\section{Evaluasi Pelaksanaan Komponen Prosedur Classroom Assessment}

Berdasarkan analisis angket yang diberikan guru, kepala madrasah, dan siswa tentang prosedur classroom assessment menghasilkan temuan bahwa angket yang diberikan guru menunjukkan $89,30 \%$ berada pada kategori baik, untuk kepala sekolah $89,92 \%$ berada pada kategori baik, serta untuk siswa $87,79 \%$ berada pada kategori baik. Bila dikaji antara angket guru, kepala madrasah dan siswa terdapat menunjukkan bahwa prosedur classroom assessment yang terdapat di MTS DDI Seppange telah baik. 
Evaluasi terhadap prosedur classroom assessment yang dilakukan dengan kuesioner guru tentang pembuatan kisi-kisi soal menghasilkan temuan 89,73\% sering membuat kisi-kisi soal, dan 10,27\% menyatakan kadang-kadang guru membuat kisi-kisi. Berdasarkan hasil wawancara dan pengamatan dokumentasi, baik yang mengatakan sering membuat kisi-kisi soal maupun yang menyatakan kadang-kadang membuat kisi-kisi soal memiliki dokumetasi terkait dengan kisi-kisi soal yang dibuat oleh para guru di MTS DDI Seppange.

Analisis butir soal terkait dengan tingkat kesukaran dan daya beda butir soal berdasarkan dari angket yang diberikan guru menunjukkan bahwa $75 \%$ guru menyatakan melakukan analisis butir soal dan $25 \%$ guru menyatakan jarang melakukan analisis butir soal. Hasil dari dokumentasi terkait dengan analisis butir soal ditemukan dokumen hasil analisis butir soal yang telah dilakukan oleh guru di MTS DDI Seppange.

Alasan guru tidak melakukan analisis butir soal adalah karena sudah banyak buku-buku latihan soal-soal yang beredar sehingga guru mengambil langsung soal yang sesuai dengan kompetensi dasar yang diajarkan.

Guru di MTS DDI Seppange telah menyusun instrumen baik terkait dengan aspek sikap (afektif), pengetahuan (kognitif) dan keterampilan (psikomotorik) belum optimal disebabkan guru menyusun instrumen mengacu pada guru mata pelajaran lainnya dengan mencocokkan dengan materi ajarnya saja.

guru di MTS DDI Seppange telah melaksanakan penilaian namun belum optimal. karena masih minimnya kemampuan guru untuk menguasai dan memahami macam-macam penilaian dan tekhnik-tekhnik penilaian sehingga terkadang para guru terfokus hanya pada satu jenis penilaian saja padahal masih banyak jenis penilaian yang layak untuk diterapkan untuk mengukur kemampuan siswa.

Berdasarkan data dilapangan menunjukkan bahwa terdapat jadwal pelaksanaan program remedial dan pengayaan yang telah dicanangkan oleh pihak MTS DDI Seppange namun disisi lain salah satu kelemahan program pengayaan dan remedial ini karena tidak memperhatikan analisis kebutuhan madrasah dan analisis kebutuhan siswa sehingga yang ada program ini lebih bersifat formalitas tanpa memperhatikan aspek kualitasnya suatu program. Berdasarkan nilai yang dicapai siswa guru melaksanakan remedial dan pengayaan. 
Guru telah memberikan materi sesuai dengan hasil analisis kesulitan siswa namun belum optimal hal ini didasari pada fakta yang ada bahwa mayoritas guru hanya lebih terfokus pada ketuntasan materi ajar bukan berdasarkan analisis kesulitan siswa. Padahal melakukan analisis berdasarkan kesulitan belajar siswa akan sangat mempengaruhi kemampuan siswa dalam mencerna materi ajar, hal ini disebabkan di dalam kelas terdapat heterogonitas kemampuan siswa ada siswa yang mempunyai kemampuan dalam segi kognitif, afektif dan psikomotorik, bahkan ada juga siswa yang memiliki kemampuan rendah, sehingga dibutuhkan analisis kesulitan belajar siswa karena dikhawatirkan dalam pemberian tes-tes soal guru melakukan penyetaraan antara siswa yang memiliki kemampuan tinggi dengan siswa yang memiliki kemampuan rendah. Sehingga disini diharapkan para guru mampu mengkombinasikan antara kesulitan belajar siswa dengan ketuntasan materi ajar.

Guru telah menentukan cara melaksanakan program remedial dan pengayaan namun program remedial hanya sifatnya formalitas dan tidak mengutamakan pada analisis kebutuhan serta hasil dari program remedial, untuk itu perlu adanya analisis kebutuhan serta kemampuan pengelola agar supaya kegiatan tersebut dapat berjalan efektif dan dari segi kualitas mampu menghasilkan output program sesuai yang diharapkan.

Guru telah memberikan laporan secara berkala kepada kepala madrasah dan orang tua siswa namun berdasarkan data di lapangan guru hanya memberikan laporan pada kepala madrasah dan tidak ada data yang menunjukkan kalau guru memberikan laporan kepada orang tua siswa, selain itu dalam pemberian laporan tersebut hanya lebih bersifat formatif saja karena tidak ada output dari laporan tersebut padahal substansi dari sebuah laporan sebagai bahan evaluative sehingga mampu memperbaiki kekurangan dan kelemahan yang ada serta dengan adanya laporan tersebut pihak guru dan madrasah menetapkan langkah-langkah yang harus ditempuh agar di tahun berikutnya tidak mengalami kemunduran dan mengalami peningkatan.

Berdasarkan aspek, teknik, dan prosedur Penilaian penilaian terhadap ketiga aspek tersebut dapat disimpulkan bahwa dari segi pelaksanaan sudah berjalan dengan baik namun belum secara optimal sehingga dibutuhkan berbagai pihak untuk mengoptimalkan ketiga aspek tersebut yang tentunya untuk meningkatkan 
kualitas pembelajaran, serta dibutuhkan peran pemerintah agar supaya konsep pengembangan kualitas pembelajaran dapat berjalan dengan baik, dari segi perencanaan yang telah dicanangkan oleh para guru, komite sekolah, maupun kepala madrasah sudah terlaksana.

Dari segi prosedur classroom Assesment para guru telah melaksanakan namun apa yang telah dilakukan belum mengarah kepada analisis kebutuhan siswa, karena prosedur yang dilaksanakan hanya bersifat formalitas serta jauh dari analsisis pengembangan kompetensi siswa

\section{KESIMPULAN}

Guru telah melaksanakan penilaian meliputi tiga aspek yaitu penilaian Afektif (sikap), Kognitif, (pengetahuan) dan Psikomotorik (keterampilan). Teknik penilaian yang dilaksanakan dan dikembangkan guru di MTS DDI Seppange adalah tes tertulis, tes lisan, observasi, tes praktik, penugasan, penilaian potofolio, jurnal, penilaian diri, dan penilaian antarteman. Prosedur penilaian yang ditempuh guru telah terlaksana. Aspek-aspek yang belum memperlihatkan kinerja yang optimal seperti kegiatan remedial serta pengayaan (enrichment). Para guru cenderung terbiasa dengan rutinitas mengajar sebagaimana biasanya yang dilakukan di dalam kelas. Perbedaan layanan hanya pada percepatan materi belajar sesuai dengan target mengajar pada setiap semester.

\section{DAFTAR PUSTAKA}

[1] Anderson, Lorin W, dan David R. Krathwohl. Classroom Assessment: Enhancing the Quality of the Teacher Decision Making. London: Publisher, 2003.

[2] Arikunto, Suharsimi dan Cepi Safruddin Abdul Jabar. Evaluasi Program Pendidikan: Pedoman Teoritis Paraktis Bagi Mahasiswa dan Praktisi Pendidikan. Jakarta: Bumi Aksara, 2009.

[3] Bungin, M. Burhan. Penelitian Kualitatif: Komunikasi, Ekonomi, Kebijakan Publik, dan IImu Sosial lainnya. Jakarta: Kencana, 2009.

[4] Effendi, Sofian. Proses Penelitian Survai, Metode Penelitian Survai. Jakarta: LP3ES, 1995. 
[5] Hayat, Bahrul. Prinsip-prinsip dan Strategi Penilaian di Kelas. Jakarta: Puspendik Balitbang Kementerian Pendidikan Nasional, 2010.

[6] Kamil, Yulbetri. dan Tjaturingsih Rosdiana. Penilaian IImu Pengetahuan Alam. Jakarta: Puspendik Balitbang Departemen Pendidikan Nasional, 2008.

[7] Mardapi, Djemari. Rekayasa sistem Penilaian dalam Rangka Meningkatkan Kualitas Pendidikan. Yogyakarta: HEPI, 2005.

[8] Mundilarto. Penerapan Penilaian Otentik dalam Mata Pelajaran Fisika. Yogyakarta: FMIPA, 2005.

[9] Muslich, Masnur. Kurikulum Tingkat Satuan Pendidikan Dasar Pemahaman dan Pengembangan. Jakarta: Bumi Aksara, 2007.

[10] Sudjana, Djudju. Evaluasi Program Pendidikan Luar Sekolah. Bandung: RemajaRosdakarya, 2006.

[11] Sudjana, Nana dan Ibrahim. Penelitian dan Penilaian Pendidikan. Bandung: Sinar Baru Algensindo, 2004.

[12] Sugiyono. Memahami Penelitian Kualitatif. Bandung: Alfabeta, 2010.

[13] Tola, Burhanuddin. Penilaian Diri. Jakarta: Puspendik Badan Penelitian dan pengembangan Kementerian Pendidikan Nasional, 2010.

[14] Peraturan Pemerintah Republik Indonesia No.19 tahun 2005 tentang Standar Nasional Pendidikan.

[15] Undang-Undang Republik Indonesia Nomor 20 Tahun 2003 tentang Sistem Pendidikan Nasional. 